\author{
International Journal of Sustainable Development \& World \\ Policy \\ 2021 Vol. 10, No. 2, pp. 64-80. \\ $\operatorname{ISSN}(e): 2305-705 \mathrm{X}$ \\ $\operatorname{ISSN}(p): 2306-9929$ \\ DOI: 10.18488/journal.26.2021.102.64.80 \\ (C) 2021 Conscientia Beam. All Rights Reserved.

\title{
EFFECTS OF GREEN HUMAN RESOURCE MANAGEMENT ON EMPLOYEE GREEN BEHAVIOR: MODERATING ROLE OF EMPLOYEE ENVIRONMENTAL KNOWLEDGE
}

(D) Kajol Karmoker ${ }^{1+}$
(D) Farhana Amin
Kona $^{2}$
(D) Amanta Hasnat
Oyshi $^{3}$
(D) Kazi Snigdha
Yasmin $^{4}$

Article History

Received: 1 July 2021 Revised: 28 July 2021

Accepted: 19 August 202

Published: 13 September 2021

\section{Keywords}

Green HRM

On-the-job green behavior

Off-the-job green behavior

Environmental knowledge

Garments industry

Bangladesh.

JEL Classification:

M140, M540

\author{
${ }^{\prime}$ Assistant Professor, Human Resource Management Discipline, Khulna \\ University, Bangladesh. \\ 'Email:Kajol.bad@gmail.com Tel: +8801723329305 \\ ${ }^{2, s, 4}$ Research Student, Human Resource Management Discipline, Khulna \\ University, Bangladesh. \\ ${ }^{2}$ Email:farhanareeya16@gmail.com Tel: +8801763966339 \\ ${ }^{3}$ Email:amantaoyshiso@gmail.com Tel: +8801627983390 \\ ${ }^{4}$ Email: kazirosy11@gmail.com Tel: +8801711309852
}

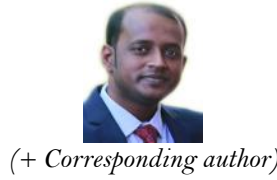

(+ Corresponding author)

\section{ABSTRACT}

The study was conducted with an objective of measuring the effects of green human resource management (green HRM) practices on employee on-the-job and off-the-job green behavior within the context of garments industry in Bangladesh. Moreover, the study tested the moderating effects of employee environmental knowledge on the relationship between green HRM practices and employee on-the-job and off-the-job green behavior. A self-administered questionnaire survey was conducted in order to collect data from the participants. Two hundred and seventy employees working at the managerial level of garments factories in Bangladesh participated in the survey. Moderated regression analysis was employed to test the proposed research model. The study findings revealed that green HRM practices positively and significantly influenced employee on-the-job and off-the-job green behavior. This findings suggest that employee green behavior displayed both inside and outside the organization stem from the learnings and experiences inside the organization. Employee environmental knowledge was also found to moderate the effects of green HRM practices on employee on-the-job and off-the-job green behavior indicating that green HRM effects are stronger in case of environmentally concerned employees. The study findings provide HR professionals and policy makers with the guidance regarding the promotion of employee green behavior for improving environmental performance.

Contribution/Originality: This study contributes to the existing literature by exploring the effects of green HRM practices on both employee on-the-job and off-the-job green behavior which has not been previously incorporated in other studies of green HRM practices.

\section{INTRODUCTION}

Environmental sustainability is increasingly gaining attention to the business world. Climate change, depletion of natural resources, and greenhouse gas emission have become the major causes of being concerned with the issue of environmental sustainability (Asadi et al., 2020). To ensure the environmental sustainability, business organizations need to mitigate business activities' negative impacts on the environment though the adoption of green initiatives or policies. As part of the green initiatives, many firms are beginning to adopt green HRM which is recognized as crucial tool for achieving the organizational green goals (Ren, Tang, \& Jackson, 2018). Green HRM refers to the systematic alignment of human resource management practices with the environmental goals (Jabbour, 
De Sousa Jabbour, Govindan, Teixeira, \& De Souza Freitas, 2013) Proper integration of environmental sustainability into human resource policies is essential since successful implementation of organizational green initiatives depends on the pro-environmental behavior of employees (Saeed et al., 2019). Kim, Kim, Choi, and Phetvaroon (2019) also emphasized the consideration of employee behavioral aspects for building sustainable organization because employees are the agents to implement the organizational green initiatives (Dumont, Shen, \& Deng, 2017). Therefore, this a growing concern for the scholars to investigate the effects of organizational green initiatives like green HRM on the behavioral aspects of the employees. Previously, green HRM has been studied in many industries, such as manufacturing industry (Dumont et al., 2017; Hameed, Khan, Islam, Sheikh, \& Naeem, 2020; Singh, Giudice, Chierici, \& Graziano, 2020; Yong et al., 2020; Yusliza et al., 2019) service industry (Song, Yu, \& Xu, 2020; Suganthi, 2019) information technology industry (Ojo \& Raman, 2019; Song et al., 2020; Suganthi, 2019) hospitality industry (Karmoker, Zannat, \& Roy, 2020; Kim et al., 2019; Pham, Tučková, \& Jabbour, 2019; Yusoff, Nejati, Kee, \& Amran, 2018) health care industry (Jia, Liu, Chin, \& Hu, 2018; Rawashdeh, 2018) higher educational institutes (Aboramadan, 2020; Fawehinmi, Yusliza, Mohamad, Faezah, \& Muhammad, 2020; Gilal, Ashraf, Gilal, Gilal, \& Channa, 2019) automobile industry (Chaudhary, 2019) coal and power industry (Saeed et al., 2019). But, green HRM has seldom been studied in the garments industry which is considered as one of the booming industries of the world, creating employment opportunities for millions of people (Sarkar, Qian, \& Peau, 2020b). Therefore, the current study intends to study green HRM practices within the context of garments industry in Bangladesh.

Bangladesh is such a country which is blessed with ready-made garments (RNG) industry where 20 million people are working for securing their livelihood (Aktar \& Islam, 2019). Labor intensive readymade garments (RMG) industry is the largest single industrial employer in Bangladesh (Carlson \& Bitsch, 2018) generating approximately 20 billion USD earnings per year (World Bank, 2013). In Bangladesh, this industry is the key source of economic development, contributing significantly towards the government's efforts of becoming a middle-income economy by 2021 (Sarkar, Qian, \& Peau, 2020a). Like any other growing industries, RMG industry is also responsible for higher level of toxic waste disposal, greenhouse gas emission and depletion of natural resources since it is high-energy and natural resources dependent industry (Talapatra \& Uddin, 2017). Water pollution, dyes mixture emissions, allied materials, contaminants, and chemical mixes during the manufacturing process of garments factory result in increased level of environmental degradation (Vandevivere, Bianchi, \& Verstraete, 1998; Yaseen \& Scholz, 2018). So, the RMG industry has incredible effects on environmental sustainability which is nowadays a global concern and a major challenge (Hossain, Sajib, \& Hafiz, 2017). As a result, the industry is faced with global pressure of adopting green business practices on a sustainable basis for protecting the environment (Aziz, Yasmin, \& Sultana, 2020). In Bangladesh, few private factories in RMG industry are relentlessly trying to ensure environmental sustainability by advancing green policies like green HRM practices (Sarkar et al., 2020b) because environmental sustainability is impossible without the environmental awareness among the managers and workforces (Aziz et al., 2020).

Existing empirical studies have examined the effects of green HRM on individual performance such as employee pro-environmental behavior (Saeed et al., 2019; Safari, Salehzadeh, Panahi, \& Abolghasemian, 2018; Suganthi, 2019) in-role and extra-role green workplace behavior (Aboramadan, 2020; Dumont et al., 2017; Zhang, Luo, Zhang, \& Zhao, 2019) task related green behavior and voluntary green behavior (Chaudhary, 2019) organizational citizenship behavior (Hameed et al., 2020) and environmental performance (Gilal et al., 2019; Rawashdeh, 2018). Nevertheless, the scholars have paid little attention on the effects of green HRM practices on employees' off-the-job green behavior in addition to the on-the-job green behavior. But, many pro-environmental behaviors demonstrated outside the workplace settings like personal lives are found similar to those displayed inside the workplace settings (Paillé, Raineri, \& Boiral, 2017). Environment friendly behavior like purchasing organic foods, recycling materials, and saving water and energy may stem from the learning, experiences, routines, 
and habits acquired inside the workplace. But little attention has been paid to discover how the environmental experience learned from the workplace settings can be transmitted in the non-work settings, such as home-work, transport, education, and consumption. Consequently, the current study addresses the gap by exploring how the organizational green initiatives like green HRM affect employee green behavior both on-the- job setting and offthe-job settings. Even the prior studies have explored the moderating role of individual green values (Dumont et al., 2017; Gilal et al., 2019; Hameed et al., 2020) environmental values and gender (Chaudhary, 2019) on the relationship between green HRM and employee green behavior. Few studies have shown how the environmental knowledge can moderate the effects of green HRM on employee pro-environmental behavior. But, employee environmental knowledge is expected to positively moderate the relationship between green HRM practices and pro-environmental behavior (Saeed et al., 2019). Hence, the current study aims to discover whether employee environmental knowledge can influence the link between green HRM and employee green behavior.

Thus, the goal of this study is twofold. First, the study seeks to examine the effects of green HRM on employees' on-the-job and off-the-job green behavior. Next, the study aims to investigate the moderating role of employees' environmental knowledge on the association between green HRM and on-the-job as well as off-the-job green behavior of employees. The study contributes to the existing literature by extending the effects of green HRM on employees' on-the-job and off-the-job behavior. In short, the study enhances the understanding of green HRM by exploring how workplace learning can have a positive effect on employees' personal lifestyle and behavior. Moreover, our research contributes by exploring the moderating role of employee environmental knowledge on the effects of green HRM within the context of garments industry in Bangladesh. Figure 1 presents the conceptual framework of the study.

The remainder of this paper is organized as follows: Section 2 presents the theoretical foundation and literature review of green HRM, environmental knowledge, on-the-job green behavior, and off-the-green behavior to develop hypotheses. Information of research methods and materials is discussed in section 3, followed by the result and analysis in section 4. Section 5 section focuses on the result discussion. Finally, section 6 discusses theoretical and practical implications, limitations, and future research direction.

\section{THEORETICAL FRAMEWORK AND HYPOTHESES DEVELOPMENT}

\subsection{Ability Motivation Theory}

We draw upon the ability-motivation-opportunity (AMO) theory developed by Appelbaum, Bailey, Berg, Kalleberg, and Bailey (2000) to examine and explain the link between green HRM and employees' on-the-job and off-the-job green behavior within the context of garments industry in Bangladesh. The AMO theory is frequently used to investigate HRM performance link as the theory suggests that employee performance is influenced by the HRM practices (Jiang, Lepak, Hu, \& Baer, 2012). According to AMO theory, HRM practices enhance organization's human capital which in turn result in increased organizational performance such as waste reduction and increased product or service quality (Appelbaum et al., 2000). AMO theory explains that once the employees' ability increases via recruitment, selection, training, and development or the employees become motivated by the rewards, incentives, and compensation or the opportunities are given to take part in teamwork and decision making process, they contribute towards the attainment of organizational goals through their performance (Gerhart, 2005). This argument is also supported by Fawehinmi et al. (2020) who claimed that HRM practices enhances organizational environmental performance if the employees are equipped with necessary ability, motivation, and opportunities to display pro-environmental behavior. Consequently, green HRM contributes to organizational green performance by recruiting employees with green values and green knowledge, motivating them through green training and incentives, and providing them with opportunities of green involvement programs, such as knowledge sharing and environmental problem solving activities (Renwick, Redman, \& Maguire, 2013). Since employees with green values remain passionate about the environment, they don't resist environmental sustainability programs initiated by the 
organization (Jia et al., 2018). And if these employees are trained with green skills and compensation is set by the environmental performance, they become motivated more to protect the environment (Ren et al., 2018). Finally, if these employees are given the opportunities to take part in decision making process through knowledge sharing and problem solving activities, they become committed more to the environment (Saeed et al., 2019). Henceforth, the current study adopts AMO theory to examine the effects of green HRM practices on employee on-the-job and offthe-green behavior within the context of garments industry in Bangladesh.

\subsection{Green HRM}

Green HRM can be defined as a set of HRM activities that have positive impact on the environment (Kramar, 2014). Expanding the definition, Anwar et al. (2020) stated that "Green HRM is the inclusion of environment consciousness within the whole HRM process of hiring, training, rewarding and developing a green workforce that understands and values environment-friendly values, practices, and initiatives". Aboramadan (2020) clarified green HRM as the means of recruiting and selecting workforces with green knowledge and values, training and developing green human capital, establishing green standards to appraise performance and providing green rewards on the successful execution of green strategies of the organization. Green HRM practices are also referred to as "HRM practices that promote environmental awareness among staff and refine their behaviors to create environment friendly attitudes in their private and working life" (Saeed et al., 2019). Henceforth, the main motive of Green HRM is to habituate employees of the organization for going green through the adoption of green initiatives, practices or policies, which in turn brings benefits for their organization as well as for the society (Arulrajah, Opatha, \& Nawaratne, 2015). Shaban (2019) viewed those practices as green HRM practices that have environmental application, such as green HR planning, green staffing, and green promotion. In a broader view, green HRM consists of five practices namely green recruitment and selection, green training and development, green performance management and appraisal, green pay and rewards, and green involvement and participation (Tang, Chen, Jiang, Paille, \& Jia, 2018). Green recruitment and selection denotes the process of hiring those individuals who have environmental knowledge and skills and those who behave in an environment friendly way (Aranganathan, 2018; Rawashdeh, 2018). This is viewed as an important dimension of green HRM practices (Likhitkar \& Verma, 2017). Green training and development is a process of creating environmental concerns among the workforce and motivating them to learn environment protection skills (Jabbour, 2011; Zoogah, 2011). Green training shapes employee behavior in a way that makes them more aware about environmental issues which ultimately discourage them from doing any harmful acts for the environment (Norton, Zacher, Parker, \& Ashkanasy, 2017). Since, all the green HRM practices reciprocally reinforce each other (Renwick et al., 2013) employee green training needs are assessed through green performance management and appraisal (Ren et al., 2018). Green performance management and appraisal refers to the system of evaluating employee outcomes in the light of environmental management standards (Jabbour, 2011) such as carrying on environmental responsibilities, reducing carbon emission, reducing wastage of resources, communicating environmental concerns etc. (Saeed et al., 2019). Hermann, Kroeze, and Jawjit (2007) argued that green performance management and appraisal affect the effectiveness of subsequent green rewards and compensation which is defined as the process of using financial and nonfinancial rewards to attract, motivate and retain employees so that they can contribute towards the achievement of environmental goals (Jabbour et al., 2013). Furthermore, Tang et al. (2018) argued that in addition to green pay and rewards, employee green involvement or participation in environmental management programs is another element of green HRM to enhance organization's environmental performance.

\subsection{Employee Green Behavior}

Employee green behavior is found as a fundamental tool of enhancing environmental performance and organizational sustainability (Chaudhary, 2019; Gilal et al., 2019). It is a source of competitive advantage because 
employees are the agents to successfully implement the green initiatives and policies taken by the organization (Fawehinmi et al., 2020). Ones and Dilchert (2012) defined employee green behavior as those friendly behavior that contributes to the achievement of environmental sustainability targets in the workplace. Furthermore, Unsworth, Dmitrieva, and Adriasola (2013) depicted employee green behavior as those behaviors that have positive effects on the environment. Alternatively, it can be described as those course of actions of employee that help minimize negative impacts on the environment, such as conserving water, saving energy, turning off light while out of office, printing double side, using bicycles to commute, avoiding wastage of resources, recycling materials, and supporting organizations to implement green strategies (Blok, Wesselink, Studynka, \& Kemp, 2015; Norton, Parker, Zacher, \& Ashkanasy, 2015).

So far, employee green behavior has been segregated into different dimensions, such as voluntary green behavior and task green behavior (Norton et al., 2015) in-role and extra-role green behavior (Dumont et al., 2017). In-role or task green behavior is the behavior that is essential for performing the formal job duties and that is considered as a part of the job description, such as minimizing paper wastage and recycling (Dumont et al., 2017; Norton et al., 2015). Extra-role or voluntary green behavior is the behavior that is not expected by the organization and that is not formally recognized in performance appraisal (Norton et al., 2015; Paillé \& Boiral, 2013). This behavior is beyond the required duties of employees and this is triggered by the personal initiatives of employee, such as turning of computer or light after work (Fawehinmi et al., 2020).

The current study divides employee green behavior into on-the-job and off-the-job green behavior. This segregation is supported by Paillé et al. (2017) who partitioned employee green behavior as private green behavior (PGB) and organizational citizenship behavior for the environment (OCBE). For clarity, on-the- job green behavior refers to the behavior that happens inside the organization, such as switching off computer and other office equipment after office hour, encouraging colleagues to conserve water or electricity, using electronic media to reduce the use of paper in office, bringing new ideas to address the environmental issues in the organization, supporting organization to implement green initiatives, and sharing environmental knowledge with co-workers (Chaudhary, 2019; Dumont et al., 2017; Saeed et al., 2019; Safari et al., 2018). On the other hand, off-the-job green behavior denotes the environmental friendly behavior displayed outside the organization, such as buying organic fruits and vegetables for consumption, avoiding products with plastic packaging, buying the products that can be reused or recycled, avoiding unnecessary consumption of electricity, gas or water at home, keeping oneself aloof from throwing waste here and there, leaving the car at home for short distances, and encouraging others to adopt environment friendly behavior (Paillé et al., 2017).

\subsection{Green HRM and Employee Green Behavior}

Green HRM literature suggests that green HRM practices stimulate employee green attitudes and behavior to protect the environment (Chaudhary, 2019; Gilal et al., 2019). Green HRM promotes employee pro-environmental behavior in their personal and work lives by engaging themselves in greener activities (Cincera \& Krajhanzl, 2013). Green HRM practices normally includes five dimensions namely recruitment and selection, training and development, performance management, remuneration and incentive systems, and participation (Shah, 2019; Tang et al., 2018). According to AMO theory, considering environmental knowledge, concern, and green values in the employee recruitment and selection process, making new employees familiar with the organizational green efforts, providing employees with green training, setting environmental goals and targets, providing regular feedback to the employees, and introducing financial and nonfinancial rewards for green practices are most likely to increase employee responsible behavior towards the environment (Renwick et al., 2013). This is because green recruitment and selection, green training and development, green performance appraisal, green rewards and compensation, and green empowerment provide employees with a signal of what is expected from them and what are the benefits of those practices, which in turn increase employee environmental commitment and motivation to display green 
behavior in the workplace (Mishra, 2017). This argument is supported by Tseng, Tan, and Siriban-Manalang (2013) who suggested that designing green work environment, providing green training and regular feedback can encourage employees in pro-environmental behavior in the workplace settings. Even if the employees are given opportunities to participate in green initiatives, they are more likely to contribute towards the achievement of green goals through their creativity and innovative solutions to the environmental problems (Chaudhary, 2019). Based on the findings, Chaudhary (2019); Zhou and Zhang (2018) concluded that green HRM practices can predict both taskrelated and voluntary employee green behavior. Furthermore, in the very recent attempts, Aboramadan (2020); Kim et al. (2019); Zhang et al. (2019); Dumont et al. (2017) claimed that green HRM practices directly or indirectly affect employee in-role and extra-role green behavior in the workplace. But employee engagement in greener activities may affect both workplace green behavior and personal lives green behavior (Cincera \& Krajhanzl, 2013) since it has been found that many pro-environmental behavior displayed in the work settings or inside the organization are analogous to green behavior demonstrated in the non-work settings, such as personal lives (Paillé et al., 2017). Employee pro-environmental behavior exhibited in their daily lives, such as purchasing organic foods, avoiding plastic packaged products, recycling materials, and saving water and energy may stem from the workplace learning, experiences, routines, and habits. As a result, green HRM practices may be expected to affect both on-thejob and off-the-job green behavior. Thus the authors propose the following:

H1: Green HRM relates positively to employee on-the-job green behavior.

H2: Green HRM relates positively to employee off-the-job green behavior.

\subsection{Environmental Knowledge as a Moderator}

Environmental knowledge is referred to as the degree of concerns regarding environmental problems and solutions (Zsóka, Szerényi, Széchy, \& Kocsis, 2013). Cheng and Wu (2015) also described environmental knowledge as the knowledge over environmental challenges and possible solutions of those challenges whereas Fryxell and Lo (2003) stated environmental knowledge as a kind of common knowledge, such as environmental protection, natural environments, ecosystems, etc. People who are environmentally knowledgeable can use their knowledge to filter the environmental facts, solve the environmental problems, and appreciate the effectiveness of environmentally friendly activities (Frick, Kaiser, \& Wilson, 2004). Several studies suggest that environmental knowledge affect the employees' intention to be engaged in pro-environmental behavior (Afsar, Badir, \& Kiani, 2016; Saeed et al., 2019; Zsóka et al., 2013). Employees who have knowledge regarding environmental management, waste management, and efficient use of resources show the highest propensity to display pro-environmental behavior at workplace, such as turning of computer, light, fan after office hour, conserving water and electricity, printing double sided paper, using electronic media to reduce the use of paper, avoiding usage of disposable cups for tea, and using stairs instead of elevators (Barr, 2007). Tudor, Barr, and Gilg (2008) agreed that a personnel with knowledge regarding the waste management is more likely to display sustainable behavior. So, environmental knowledge and awareness has a direct effect on managers' green behavior at the workplace (Safari et al., 2018).

Environmental knowledge is also expected to affect the green behavior in the non-work settings, such as green consumption in the private life. This argument is supported when (Chan, Hon, Chan, \& Okumus, 2014) proved that consumers concerned with the environmental issues are most likely to purchase organic foods, products with ecofriendly labels and recycle waste. Sometimes, consumers exhibiting higher degree of environmental knowledge intend to pay more for green products (Bang, Ellinger, Hadjimarcou, \& Traichal, 2000). Environmental knowledge can refrain the individuals from behaving in a particular way (Saeed et al., 2019). For example, people do not use hair sprays anymore after knowing the environmental impacts of chlorine fluoride (Chan et al., 2014). So, the more environmental knowledge an individual has, the greater the possibility that the individual would behave in an environment friendly manner (Cheng \& Wu, 2015; Frick et al., 2004). 
Though it is well established that green HRM practices affect employee green behavior, the relationship is likely to be moderated by the employee environmental knowledge (Saeed et al., 2019). This argument is reinforced by Afsar et al. (2016) who proved that interaction between environmental knowledge and green HRM strengthens the aforementioned relationship and increases employees' participation in green behavior. Referring to Schwartz (1977) norm activation model (NAM), Han, Hwang, Kim, and Jung (2015) also agreed that environmental knowledge used as a moderator rather that direct effect helps the activation process of environment friendly behavior. Henceforth, the study proposes that employee environmental knowledge will moderate the effects of green HRM on employee on-the-job and off-the-job green behavior. As such, we develop the following hypotheses:

H3: Employee environmental knowledge moderates the effect of green HRM on employee on-the-job green behavior such that the effect is stronger when the employees have more environmental knowledge and weaker when less.

H4: Employee environmental knowledge moderates the effect of green HRM on employee off-the-job green behavior such that the effect is stronger when the employees have more environmental knowledge and weaker when less.

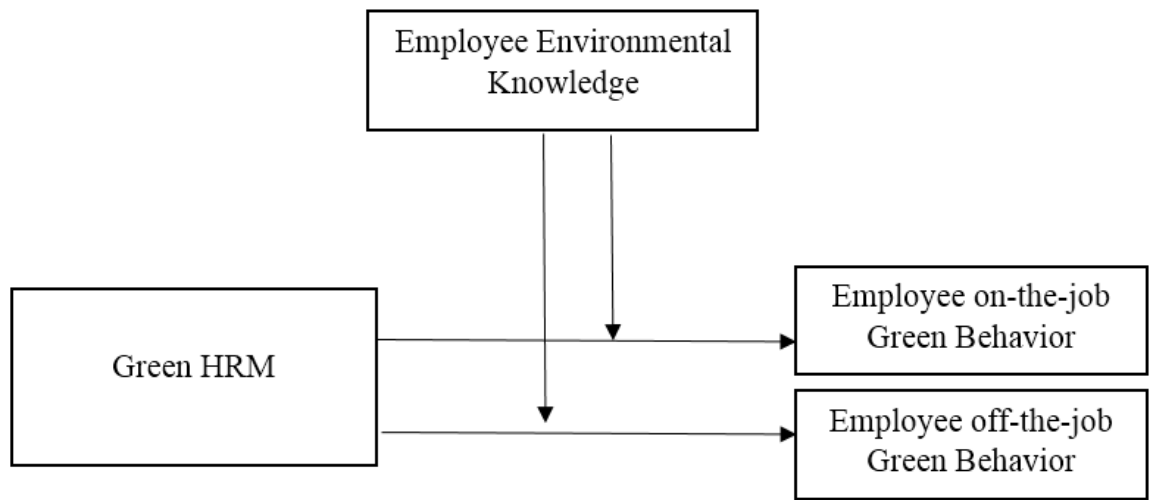

Figure-1. Conceptual framework.

\section{METHODOLOGY}

\subsection{Participants and Procedure}

This study employed a quantitative research approach to examine the impact of green HRM on employees' onthe-job and off-the-job green behavior along with the moderation effects of employee environmental knowledge. To test the conceptual model and hypothesized relationship, a survey instrument and measurement scales were developed. At first, a draft questionnaire was constructed and a pretest was performed to check the content validity of the questionnaire. According to the feedback of pretest, the content of the questionnaire was improved with the help of industry experts and academics of Human Resource Management Discipline, Khulna University, Bangladesh. The questionnaire was then finalized and used to collect data for testing the proposed hypotheses. The developed questionnaire had two sections. First section was designed with a total of 27 close ended items measuring green HRM, employee on-the-job green behavior, employee off-the-job behavior, and employee environmental knowledge. Second section of the questionnaire was designed with 6 questions regarding respondents' demographic information, such as name, age, gender, income, working experience, and designation.

Data were collected from the readymade garments (RMG) employees at the managerial level through the selfadministered questionnaire survey. The survey took place between October 2020 and December 2020. The garments employees were selected from the large sized garments factories situated in Dhaka, Gazipur, and Savar city which are considered as the main hub of garments industry in Bangladesh. Large sized garments factories were chosen because they have formalized the human resource management systems, they are sensitive to the environmental issues, and they are bound to maintain internationally set environmental standards because of the global growing concerns for eco-friendly practices and products. Initially, the HR department of those factories were contacted for selecting the sample employees. HR mangers provided us with employee directory from where 
the employees were selected. A total of 400 questionnaires were distributed either face to face or through email. In total, 313 questionnaires were returned, of which 270 questionnaires were found valid representing a response rate of 67.50 per cent. The response rate was acceptable since the minimum sample size was determined 266 according to the formula: $\mathrm{N}>50+8 \mathrm{~m}$ (where $\mathrm{m}=$ number of questions of independent variables) developed by Tabachnick and Fidell (2001). Therefore, the 270 respondents in this study can be considered adequate for testing the hypotheses. The demographic features of the respondents are shown in Table 1.

\subsection{Measurements}

Green HRM was measured using a 6 item scale adapted from Dumont et al. (2017) with slight modification as per the research context. The items are "assessing green knowledge, attitudes, and skills while selecting any employee," "providing employees with green training to develop green knowledge, attitudes and skills," "considering employees' workplace green behavior in performance appraisals," "setting green goals for its employees in order to achieve the organizations' environmental goals," "relating employees' workplace green behaviors to rewards and compensation" and "considering employees' workplace green behavior in promotion". Responses over all the items were asked on a 5 point Likert scale ranging from 1 "strongly disagree" to 5 "strongly agree".

We measured employees' on-the-job green behavior by a 7 item scale developed by Safari et al. (2018). The items are "bringing new ideas to address the environmental issues in the organization," "taking part in the environment friendly programs of the organization," "sharing knowledge about the environment protection issues with co-workers," "turning off fan, light, AC or other office equipment after office hour," "encouraging colleagues to conserve water or electricity," "using electronic media to reduce the use of paper in office" and "encouraging others to keep the office environment neat and clean". The measurement was rated on a 5 point Likert scale ranging from 1 "strongly disagree" to 5 "strongly agree".

Employees' off-the-job green behavior was evaluated using a 7 item scale adapted from Paillé et al. (2017). The items were slightly modified according to the research context. The items were "buying organic fruits and vegetables," "avoiding products with plastic packaging," "buying the products that can be reused or recycled," "avoiding unnecessary consumption of energy like electricity, gas or water," "keeping oneself aloof from throwing waste here and there," "leaving the car at home for short distances" and "encouraging others to adopt environment friendly behavior". Answers on each item were asked on a 5 point Likert scale ranging from 1 "strongly disagree" to 5 "strongly agree".

We assessed employees' environmental knowledge using a 7 item scale developed by Saeed et al. (2019). The items are "being concerned with the environment pollution," "knowing how to protect the environment from pollution," "being aware of climate change due to environment pollution," "knowing what clean energy is and how to promote it," "knowing how the individual's behaviors can pollute the environment," "knowing how to select and consume environment friendly products" and "knowing how to save water, gas or electricity". The answers were captured on a 5 point Likert scale ranging from 1 "strongly disagree" to 5 "strongly agree".

We used nominal and ordinal scale to assess respondents' age, gender, income, and experience. The study indicated that the respondents' age, gender, income, and experience could influence the effects on employee on-thejob and off-the-job green behavior. As a result, the study controlled for the variables.

\section{DATA ANALYSIS AND RESULTS}

The survey data were analyzed using SPSS 23.0. Application of green HRM practices in the garments industry of Bangladesh were analyzed by the descriptive statistics, such as mean and standard deviation. Degree of association between the study variables was measured using correlation analysis. And the study hypotheses were tested by the moderated regression analysis. 


\subsection{Demographic Profile of the Respondents}

Table 1 presents the demographic characteristics of the respondents. Out of 270 respondents, approximately $58.1 \%$ were male and $41.9 \%$ were female. In terms of age, around $19.3 \%$ of the respondents were aged from 21 to 30 , $32.6 \%$ were aged from 31 to $40,37.8 \%$ were aged from 41 to 50 years and only $10.4 \%$ were aged above 50 . About $6.7 \%$ of the respondents had monthly income of 21,000 to $30,000 \mathrm{TK}, 35.6 \%$ had income between $31,000-40,000$ $\mathrm{TK}, 42.6 \%$ had income between 41,000-50,000 TK, and the remaining 15.2\% had income above 50,000 TK. In terms of length of service, $27 \%$ respondents had working experience of less than 2 years, $28.5 \%$ had served for 2 to 4 years, $23 \%$ had served for 5 to 7 years, $18.1 \%$ had working experience of 8 to 10 years and the rest had working experience of more than 10 years. All the respondents were the full time employees of the garments industry in Bangladesh.

Table-1. Demographic Characteristics of the Respondents $(n=270)$.

\begin{tabular}{|c|c|c|c|}
\hline Characteristics & Category & Frequency & Percentage (\%) \\
\hline \multirow{2}{*}{ Gender } & Male & 157 & 58.1 \\
\hline & Female & 113 & 41.9 \\
\hline \multirow{4}{*}{ Age } & 21-30 years & 52 & 19.3 \\
\hline & $31-40$ years & 88 & 32.6 \\
\hline & $41-50$ years & 102 & 37.8 \\
\hline & Above 50 years & 28 & 10.4 \\
\hline \multirow{4}{*}{ Income $(\mathrm{Tk})$} & $21,000-30,000$ & 18 & 6.7 \\
\hline & $31,000-40,000$ & 96 & 35.6 \\
\hline & $41,000-50,000$ & 115 & 42.6 \\
\hline & Above 50,000 & 41 & 15.2 \\
\hline \multirow{5}{*}{ Working Experience } & Less than 2 years & 73 & 27.0 \\
\hline & $2-4$ years & 77 & 28.5 \\
\hline & $5-7$ years & 62 & 23.0 \\
\hline & $8-10$ years & 49 & 18.1 \\
\hline & More than 10 years & 9 & 3.3 \\
\hline
\end{tabular}

\subsection{Descriptive Analysis}

Table 2 shows the descriptive statistics and inter-correlations of all the constructs of this study. Green HRM was found to be positively correlated with employees' on-the-job green behavior $(r=0.407, p<0.01)$ and off-the-job green behavior $(r=0.468, p<0.01)$. This findings partially support our hypotheses that green HRM practices positively correlates with the employees' on-the-job green behavior and off-the-the-job green behavior.

Table-2. Means, SD, and Inter-correlations.

\begin{tabular}{|c|c|c|c|c|c|c|}
\hline Variables & Mean & SD & 1 & 2 & 3 & 4 \\
\hline 1. Green HRM & 4.33 & 0.39 & $(0.794)$ & & & \\
\hline 2. Employees' on-the-job Green Behavior & 4.20 & 0.40 & $0.407^{* * *}$ & $(0.730)$ & & \\
\hline 3. Employees' off-the-job Green Behavior & 4.15 & 0.46 & $0.468^{* *}$ & $0.601^{* *}$ & $(0.705)$ & \\
\hline 4. Employees' Environmental Knowledge & 4.15 & 0.44 & $0.387^{* * *}$ & $0.534^{* *}$ & $0.562^{* * *}$ & $(0.744)$ \\
\hline
\end{tabular}

\subsection{Hypothesis Testing}

The study hypotheses were tested using moderated regression analysis. Moderation occurs when the strength of a relationship between independent variable and dependent variable varies due to moderating variable. As a result, we used a three stage regression analysis: (1) control variables, (2) main effects variables, and (3) interaction effect to predict the moderation effect of employee environmental knowledge on employee on-the-job and off-thejob green behavior. Firstly, the study proposed that green HRM positively correlates with employee on-the-job green behavior ( $\mathrm{H} 1)$ and the relationship is positively moderated by the employee environmental knowledge, such 
that the effect will be stronger when the employees have more environmental knowledge and weaker when less (H3). As shown in Table 3, the result revealed that green HRM was positively and significantly related to employee on-the-job green behavior $(\beta=0.228, P<0.001)$ after respondent age, gender, income, and experience were controlled for. So the hypothesis 1 was supported. Table 3 also revealed that interaction term (Green HRM x Environmental Knowledge) had positive and significant effect on employee on-the-job green behavior $(\beta=2.924, P$ $<0.001)$ which indicates that employee environmental knowledge significantly moderates the relationship between green HRM and employee on-the-job green behavior. In addition, the $R^{2}$ change (0.031) with $\mathrm{F}$ change (13.037) associated with the interaction term added $3.1 \%$ explanatory power of the independent variable. Thus hypothesis 3 was well supported.

Table-3. Results of moderated regression analysis.

\begin{tabular}{|c|c|c|c|c|c|c|}
\hline \multicolumn{7}{|c|}{ Dependent Variable: Employee On-the-Job Green Behavior } \\
\hline Predictors & Beta & t-value & p-value & F-value & $\mathbf{R}^{2}$ & Change in $\mathbf{R}^{2}$ \\
\hline $\begin{array}{l}\text { Control variables } \\
\text { Gender } \\
\text { Age } \\
\text { Income } \\
\text { Experience }\end{array}$ & $\begin{array}{c}-0.042 \\
-0.153 \\
0.119 \\
-0.100\end{array}$ & $\begin{array}{c}-0.691 \\
-2.405 \\
1.858 \\
-0.157\end{array}$ & $\begin{array}{c}0.490 \\
0.017 \\
0.064 \\
-0.876\end{array}$ & 1.948 & 0.029 & 0.029 \\
\hline $\begin{array}{l}\text { Main effects } \\
\text { Green HRM } \\
\text { Environmental Knowledge }\end{array}$ & $\begin{array}{l}0.228 \\
0.438\end{array}$ & $\begin{array}{l}4.174 \\
7.978\end{array}$ & $\begin{array}{l}0.000 \\
0.000\end{array}$ & 22.510 & 0.339 & 0.311 \\
\hline $\begin{array}{l}\text { Interaction effect } \\
\text { Green HRM x Environmental knowledge }\end{array}$ & 2.924 & 3.611 & 0.000 & 22.040 & 0.371 & 0.031 \\
\hline
\end{tabular}

Secondly, the study hypothesized that green HRM positively correlates with employee off-the-job green behavior (H2) and the relationship is positively moderated by the employee environmental knowledge, such that the effect will be stronger when the employees have more environmental knowledge and weaker when less (H4). As illustrated in Table 4, green HRM was found to be positively and significantly related to employee off-the-job green behavior $(\beta=0.292, P<0.001)$ after controlling the influence of respondent age, gender, income, and experience. Thus hypothesis 2 was supported. Table 4 also indicated that interaction term (Green HRM x Environmental Knowledge) was significant $(\beta=1.847, P<0.001)$ to moderate the relationship between green HRM and employee off-the-job green behavior. $\mathrm{R}^{2}$ change (.012) with $\mathrm{F}$ change (5.663) of the interaction term improves the prediction power of the independent variable by $1.2 \%$. Thus the result supported the hypothesized moderation relationship (H4).

Table-4. Results of moderated regression analysis.

\begin{tabular}{|c|c|c|c|c|c|c|}
\hline \multicolumn{7}{|c|}{ Dependent Variable: Employee Off-the-Job Green Behavior } \\
\hline Predictors & Beta & t-value & $p$-value & F-value & $\boldsymbol{R}^{2}$ & Change in $R^{2}$ \\
\hline $\begin{array}{l}\text { Control variables } \\
\text { Gender } \\
\text { Age } \\
\text { Income } \\
\text { Experience }\end{array}$ & $\begin{array}{c}-0.075 \\
-0.212 \\
0.109 \\
-0.079\end{array}$ & $\begin{array}{c}-1.247 \\
-3.382 \\
1.720 \\
-1.275\end{array}$ & $\begin{array}{l}0.213 \\
0.001 \\
0.037 \\
0.204\end{array}$ & 3.720 & 0.053 & 0.053 \\
\hline $\begin{array}{l}\text { Main Effects } \\
\text { Green HRM } \\
\text { Environmental Knowledge }\end{array}$ & $\begin{array}{l}0.292 \\
0.431\end{array}$ & $\begin{array}{l}5.641 \\
8.311\end{array}$ & $\begin{array}{l}0.000 \\
0.000\end{array}$ & 30.401 & 0.410 & 0.356 \\
\hline $\begin{array}{l}\text { Interaction effect } \\
\text { Green HRM x Environmental knowledge }\end{array}$ & 1.847 & 2.380 & 0.018 & 27.329 & 0.422 & 0.012 \\
\hline
\end{tabular}




\section{RESULT DISCUSSION}

Based on the AMO theory, the current study developed and tested a model in which green HRM was hypothesized to be positively related to employee on-the-job and off-the-job green behavior and employee environmental knowledge was proposed to moderate the hypothesized relationship. The findings of the study supported the hypothesized relationship. Green HRM practices positively affected employee on-the-job green behavior. This findings suggest that green HRM practices in the garments industry, such as assessing green skills and attitudes while selecting employees, providing training for efficient use of water, electricity and other resources, assessing employee performance on the green parameter, and rewarding employees for green performance encourage them more to demonstrate pro-environmental behavior on-the-job settings. This findings was in line with the findings of Saeed et al. (2019); Chaudhary (2019); Dumont et al. (2017) in which they found that green HRM practices positively affect employee workplace pro-environmental behavior classified as in-role and extra-role green behavior or task related and voluntary green behavior.

In terms of the relationship between green HRM and employee off-the-job green behavior, the study results indicated that a positive relationship exists between these two variables. This findings reveals that green HRM practices affect employee green behavior beyond the workplace settings indicating that employee green behavior demonstrated outside the workplace may stem from the on-the-job learnings and experiences. This findings does not contradict, but explain a reverse situation of the findings of Paillé et al. (2017) in which they proved how private green behavior of the employees can affect organizational citizenship behavior at the workplace whereas we investigated how organizational green initiatives can affect green behavior outside the workplace since many offthe-job green behaviors are found analogous to employee on-the-job green behaviors.

In examining the moderating effects of employee environmental knowledge on the relationship between green HRM and employee on-the-job green behavior, the study found positive and significant effects of environmental knowledge on the hypothesized relationship. This result indicates that garments employees' environmental knowledge strengthens the effects of green HRM on employee on-the-job green behavior. Thus, green HRM effects on green behavior are contingent upon employee environmental knowledge and awareness. This result reflects the findings of Saeed et al. (2019) in which they found that employee's environmental knowledge moderated the effects of green HRM practices on employee pro-environmental behavior at the workplace. Consequently, the effectiveness of green HRM practices in promoting employee on-the-job green behavior can be expected to differ according to the level of employee environmental knowledge since environmental knowledge increases the willingness of employees to participate in the pro-environmental activities at the workplace settings (Safari et al., 2018). Moderating effects of employee environmental knowledge was also found positive on the hypothesized relationship between green HRM and employee off-the-job green behavior. This result suggests that green HRM practices can predict employee off-the-job green behavior more significantly in case of the employees who are aware of the environmental problems and solutions since the environmentally knowledgeable employees are more likely to be engaged in green behavioral practices in their personal lives.

This study makes several contribution to the literature. First, by investigating the effects of green HRM on employee on-the-job and off-the-job green behavior, the study contributes to the AMO theory. Based on the AMO theory, the study findings proved that when the garments employees are hired on the basis of green job description, provided with green training for developing green skills, appraised with green performance indicators and rewarded with financial incentives for green performance, they are most likely contribute to the reduction of water pollution, dyes mixture emissions and contamination along with the efficient use of other resources in the garments factory. The study has evidenced that the positive effects of organizational green initiatives are also found in the personal lives of the employees. Employees of the garments factories where green HRM practices are present demonstrate environment friendly behavior beyond their workplace by purchasing organic foods, avoiding plastic packaged products, and encouraging others not to through waste here and there. Previously, no study has been 
found to consider green behavior displayed both in the workplace setting and non-workplace settings. Most of the green HRM focused studies considered either in-role and extra-role green behavior (Aboramadan, 2020; Dumont et al., 2017; Zhang et al., 2019) or task related and voluntary green behavior at the workplace (Chaudhary, 2019; Norton et al., 2015). Therefore, the originality of the current study is the investigation of green HRM effects on both on-the-job and off-the-job green behavior. Second, the study considers the moderating effects of employee environmental knowledge in order to discover how the effects of green HRM on employee green behavior is contingent upon employee environmental knowledge. In doing so, it added an important insight to the existing relationship between green HRM and employee green behavior. Lastly, by testing the hypothesized model over the garments industry employee in Bangladesh, the study adds to the scarce literature of green HRM practices in the emerging economies of the world.

\subsection{Practical Implications}

In the twenty-first century, RMG sector of Bangladesh performs in a profoundly aggressive global economy. The management sectors of these internationally performing factories have been confronting pressure from the stakeholders to achieve environmental sustainability and combat environmental challenges. To combat the environmental challenges, HR managers of garments factories have been provided with an extra charge of adopting green policies and practices. As a result, the findings of this study have far-reaching implications for HR practitioners in the RMG industry. Moreover, the findings of this study suggest that green practices of the organizations, such as assessing green skills and attitudes while selecting employees, providing green training for developing green skills, setting green goals, assessing employee performance on the green parameter, and rewarding employees for green performance promote on-the-job green behavior of the employees. These findings of the study will be of great interest to the HR managers and scholars of RMG sector as it outlines the role of green HRM practices and shows how it promotes on-the-job green behavior of the employees. It will help managers to understand the importance of various green HRM practices in successfully dealing with the environmental challenges. In addition to that, the study reveals that green HRM practices affect employee green behavior beyond the workplace indicating that employee green behavior demonstrated outside the workplace may stem from the onthe-job learnings and experiences. This finding of the study will add value to the understanding of how green HRM practices in the organization can affect employee off-the-job green behavior. Employee off-the-job green behavior can influence the attitudes and behaviors of their families which in fact can shape the green attitude and behavior of an entire society.

\subsection{Limitations and Future Research Directions}

The current study has few limitations that can open new door for future research. First, data were collected only from the garments industry to investigate the effects of green HRM on employee green behavior (on-the-job and off-the-job). This means that other industries should be taken into consideration in future for the generalizability of the study findings. Second, the study employed cross sectional design to test the hypothesized model. So, other research designs, such as experimental or time-lagged research design are recommended in future. Third, the study was conducted in Bangladesh. As a result, the same study can be carried out in other countries to collect more information and compare the study findings. Fourth, since the study attempted to investigate the moderating effects of employee environmental knowledge on the link between green HRM and employee green behavior, moderating effects of other individual and organizational variables, such as self-efficacy, personality, green values, organizational support can be examined for a better understanding of the relationship. Finally, the study did not show mediation effects of any variable. So, the mediating effects of employee satisfaction, environmental commitment, organizational identification, and pro-environmental psychological climate can be explored to further explain the green HRM effects on the employee on-the-job and off-the-job green behavior. 
Funding: This study received no specific financial support.

Competing Interests: The authors declare that they have no competing interests.

Acknowledgement: The authors would like to express our heartfelt gratitude to the students of Human Resource Management Discipline, Khulna University, for their active involvement in collecting the data. They are indebted to few of their faculty members who had encouraged us and provided their mental support in conducting the research. Above all, Authors would like to convey their special thanks to the respective HR body of the garments factories, for their assistance in conducting the survey and they believe that all the participants in the survey had truly expressed their opinions. Thanks to all.

\section{REFERENCES}

Aboramadan, M. (2020). The effect of green HRM on employee green behaviors in higher education: The mediating mechanism of green work engagement. International Journal of Organizational Analysis, 1-17. Available at: https://doi.org/10.1108/ijoa-05-2020-2190.

Afsar, B., Badir, Y., \& Kiani, U. S. (2016). Linking spiritual leadership and employee pro-environmental behavior: The influence of workplace spirituality, intrinsic motivation, and environmental passion. Journal of Environmental Psychology, 45, 7988. Available at: https://doi.org/10.1016/j.jenvp.2015.11.011

Aktar, A., \& Islam, Y. (2019). Green human resource management practices and employee engagement: Empirical evidence from RMG sector in Bangladesh. Retrieved from https://ssrn.com/abstract=3363860.

Anwar, N., Mahmood, N. H. N., Yusliza, M. Y., Ramayah, T., Faezah, J. N., \& Khalid, W. (2020). Green human resource management for organisational citizenship behaviour towards the environment and environmental performance on a university campus. Journal of Cleaner Production, 256, 120401. Available at: https://doi.org/10.1016/j.jclepro.2020.120401.

Appelbaum, E., Bailey, T., Berg, P., Kalleberg, A. L., \& Bailey, T. A. (2000). Manufacturing advantage: Why high-performance work systems pay off: Cornell University Press.

Aranganathan, P. (2018). Green recruitment: A new-fangled approach to attract and retain talent. International Journal of Business Management \& Research, 8(2), 69-76. Available at: https://doi.org/10.24247/ijbmrapr20189.

Arulrajah, A. A., Opatha, H., \& Nawaratne, N. (2015). Green human resource management practices: A review. Sri Lankan Journal of Human Resource Management, 5(1).

Asadi, S., Pourhashemi, S. O., Nilashi, M., Abdullah, R., Samad, S., Yadegaridehkordi, E., \& Razali, N. S. (2020). Investigating influence of green innovation on sustainability performance: A case on Malaysian hotel industry. Journal of Cleaner Production, 258, 120860. Available at: https://doi.org/10.1016/j.jclepro.2020.120860

Aziz, F. F., Yasmin, F., \& Sultana, T. (2020). The impact of green human resources managerial practices on environmental sustainability: Evidence from Garments industry of Bangladesh. Asian Journal of Empirical Research, 10(3), 81-96. Available at: https://doi.org/10.18488/journal.1007/2020.10.3/1007.3.81.96.

Bang, H.-K., Ellinger, A. E., Hadjimarcou, J., \& Traichal, P. A. (2000). Consumer concern, knowledge, belief, and attitude toward renewable energy: An application of the reasoned action theory. Psychology \& Marketing, 17(6), 449-468. Available at: https://doi.org/10.1002/(sici)1520-6793(200006)17:6\%3C449::aid-mar2\%3E3.0.co;2-8.

Barr, S. (2007). Factors influencing environmental attitudes and behaviors: A UK case study of household waste management. Environment and Behavior, 39(4), 435-473. Available at: https://doi.org/10.1177\%2F0013916505283421.

Blok, V., Wesselink, R., Studynka, O., \& Kemp, R. (2015). Encouraging sustainability in the workplace: A survey on the proenvironmental behaviour of university employees. Journal of Cleaner Production, 106, 55-67. Available at: https://doi.org/10.1016/j.jclepro.2014.07.063.

Carlson, L. A., \& Bitsch, V. (2018). Social sustainability in the ready-made-garment sector in Bangladesh: An institutional approach to supply chains. International Food and Agribusiness Management Review, 21(2), 269-292. Available at: https://doi.org/10.22434/IFAMR2017.0114. 
Chan, E. S., Hon, A. H., Chan, W., \& Okumus, F. (2014). What drives employees' intentions to implement green practices in hotels? The role of knowledge, awareness, concern and ecological behavior. International Journal of Hospitality Management, 40, 20-28. Available at: https://doi.org/10.1016/j.jjhm.2014.03.001.

Chaudhary, R. (2019). Green human resource management and employee green behavior: An empirical analysis. Corporate Social Responsibility and Environmental Management, 27(2), 630-641. Available at: https://doi.org/10.1002/csr.1827.

Cheng, T. M., \& Wu, H. C. (2015). How do environmental knowledge, environmental sensitivity, and place attachment affect environmentally responsible behavior? An integrated approach for sustainable island tourism. Journal of Sustainable Tourism, 23(4), 557-576. Available at: https://doi.org/10.1080/09669582.2014.965177.

Cincera, J., \& Krajhanzl, J. (2013). Eco-Schools: What factors influence pupils' action competence for pro-environmental behavior? Journal of Cleaner Production, 61, 117-121. Available at: https://doi.org/10.1016/j.jclepro.2013.06.030.

Dumont, J., Shen, J., \& Deng, X. (2017). Effects of green HRM practices on employee workplace green behavior: The role of psychological green climate and employee green values. Human Resource Management, 56(4), 613-627. Available at: https://doi.org/10.1002/hrm.21792.

Fawehinmi, O., Yusliza, M. Y., Mohamad, Z., Faezah, J. N., \& Muhammad, Z. (2020). Assessing the green behaviour of academics: The role of green human resource management and environmental knowledge. International Journal of Manpower, 41(7), 879-900. Available at: https://doi.org/10.1108/IJM-07-2019-0347.

Frick, J., Kaiser, F. G., \& Wilson, M. (2004). Environmental knowledge and conservation behavior: Exploring prevalence and structure in a representative sample. Personality and Individual Differences, 37(8), 1597-1613. Available at: https://doi.org/10.1016/j.paid.2004.02.015.

Fryxell, G. E., \& Lo, C. W. (2003). The influence of environmental knowledge and values on managerial behaviours on behalf of the environment: An empirical examination of managers in China. Journal of Business Ethics, 46(1), 45-69. Available at: https://doi.org/10.1023/A:1024773012398.

Gerhart, B. (2005). Human resources and business performance: Findings, unanswered questions, and an alternative approach. Management Revue. Socio-economic Studies, 16(2), 174-185. Available at: https://doi.org/10.5771/0935-9915-2005-2174.

Gilal, F. G., Ashraf, Z., Gilal, N. G., Gilal, R. G., \& Channa, N. A. (2019). Promoting environmental performance through green human resource management practices in higher education institutions: A moderated mediation model. Corporate Social Responsibility and Environmental Management, 26(6), 1579-1590. Available at: https://doi.org/10.1002/csr.1835.

Hameed, Z., Khan, I. U., Islam, T., Sheikh, Z., \& Naeem, R. M. (2020). Do green HRM practices influence employees' environmental performance? International Journal of Manpower, 41(7), 1061-1079. Available at: https://doi.org/10.1108/ijm-08-2019-0407.

Han, H., Hwang, J., Kim, J., \& Jung, H. (2015). Guests' pro-environmental decision-making process: Broadening the norm activation framework in a lodging context. International Journal of Hospitality Management, 47, 96-107. Available at: https://doi.org/10.1016/j.ijhm.2015.03.013.

Hermann, B. G., Kroeze, C., \& Jawjit, W. (2007). Assessing environmental performance by combining life cycle assessment, multi-criteria analysis and environmental performance indicators. Journal of Cleaner Production, 15(18), 1787-1796. Available at: https://doi.org/10.1016/j.jclepro.2006.04.004.

Hossain, L., Sajib, M., \& Hafiz, E. (2017). Readymade garment industries going green. The financial express: International Publications Limited.

Jabbour, C. J. C. (2011). How green are HRM practices, organizational culture, learning and teamwork? A Brazilian study. Industrial and Commercial Training, 43(2), 98-105. Available at: https://doi.org/10.1 108/00197851111108926.

Jabbour, C. J. C., De Sousa Jabbour, A. B. L., Govindan, K., Teixeira, A. A., \& De Souza Freitas, W. R. (2013). Environmental management and operational performance in automotive companies in Brazil: The role of human resource management and lean manufacturing. Journal of Cleaner Production, 47, 129-140. Available at: https://doi.org/10.1016/j.jclepro.2012.07.010. 
Jia, J., Liu, H., Chin, T., \& Hu, D. (2018). The continuous mediating effects of GHRM on employees' green passion via transformational leadership and green creativity. Sustainability, 10(9), 3237. Available at: https://doi.org/10.3390/su10093237.

Jiang, K., Lepak, D. P., Hu, J., \& Baer, J. C. (2012). How does human resource management influence organizational outcomes? A meta-analytic investigation of mediating mechanisms. Academy of management Journal, 55(6), 1264-1294. Available at: https://doi.org/10.5465/amj.2011.0088.

Karmoker, K., Zannat, T., \& Roy, B. (2020). Can green HRM practices influence hotel employees' green behavior? Evidence from Khulna City hospitality industry, Bangladesh. International Journal of Human Resource Studies, 1O(4), 149-167. Available at: https://doi.org/10.5296/ijhrs.v 10i4.17641

Kim, Y. J., Kim, W. G., Choi, H. M., \& Phetvaroon, K. (2019). The effect of green human resource management on hotel employees' eco-friendly behavior and environmental performance. International Journal of Hospitality Management, 76, 83-93. Available at: https://doi.org/10.1016/j.ijhm.2018.04.007.

Kramar, R. (2014). Beyond strategic human resource management: is sustainable human resource management the next approach? The International Journal of Human Resource Management, 25(8), 1069-1089. Available at: https://doi.org/10.1080/09585192.2013.816863.

Likhitkar, P., \& Verma, P. (2017). Impact of green HRM practices on organization sustainability and employee retention. International Journal for Innovative Research in Multidisciplinary Field, 3(5), 152-157.

Mishra, P. (2017). Green human resource management. International Journal of Organizational Analysis, 25(5), 762-788. Available at: https://doi.org/10.1108/IJOA-11-2016-1079.

Norton, T. A., Parker, S. L., Zacher, H., \& Ashkanasy, N. M. (2015). Employee green behavior: A theoretical framework, multilevel review, and future research agenda. Organization $\mathcal{E}^{2}$ Environment, 28(1), 103-125. Available at: https://doi.org/10.1177\%2F 1086026615575773.

Norton, T. A., Zacher, H., Parker, S. L., \& Ashkanasy, N. M. (2017). Bridging the gap between green behavioral intentions and employee green behavior: The role of green psychological climate. Journal of Organizational Behavior, 38(7), 996-1015. Available at: https://doi.org/10.1002/job.2178.

Ojo, A. O., \& Raman, M. (2019). Role of green HRM practices in employees' pro-environmental IT practices. Paper presented at the World Conference on Information Systems and Technologies. Springer, Cham.

Ones, D. S., \& Dilchert, S. (2012). Employee green behaviors. In S. E. Jackson, D. S. Ones, \& S. Dilchert (Eds.), The SIOP professional practice series. Managing human resources for environmental sustainability (pp. 85-116): JosseyBass/Wiley.

Paillé, P., \& Boiral, O. (2013). Pro-environmental behavior at work: Construct validity and determinants. Journal of Environmental Psychology, 36, 118-128. Available at: https://doi.org/10.1016/j.jenvp.2013.07.014.

Paillé, P., Raineri, N., \& Boiral, O. (2017). Environmental behavior on and off the job: A configurational approach. Journal of Business Ethics, 158(1), 253-268. Available at: https://doi.org/10.1007/s 10551-017-3758-1.

Pham, N. T., Tučková, Z., \& Jabbour, C. J. C. (2019). Greening the hospitality industry: How do green human resource management practices influence organizational citizenship behavior in hotels? A mixed-methods study. Tourism Management, 72, 386-399. Available at: https://doi.org/10.1016/j.tourman.2018.12.008.

Rawashdeh, A. (2018). The impact of green human resource management on organizational environmental performance in Jordanian health service organizations. Management Science Letters, 8(10), 1049-1058. Available at: https://doi.org/10.5267/j.msl.2018.7.006.

Ren, S., Tang, G., \& Jackson, S. E. (2018). Green human resource management research in emergence: A review and future directions. Asia Pacific Journal of Management, 35(3), 769-803. Available at: https://doi.org/10.1007/s 10490-017-95321. 
Renwick, D. W., Redman, T., \& Maguire, S. (2013). Green human resource management: A review and research agenda. International Journal of Management Reviews, 15(1), 1-14. Available at: https://doi.org/10.1111/j.14682370.2011.00328.x.

Saeed, B. B., Afsar, B., Hafeez, S., Khan, I., Tahir, M., \& Afridi, M. A. (2019). Promoting employee's proenvironmental behavior through green human resource management practices. Corporate Social Responsibility and Environmental Management, 26(2), 424-438. Available at: https://doi.org/10.1002/csr.1694.

Safari, A., Salehzadeh, R., Panahi, R., \& Abolghasemian, S. (2018). Multiple pathways linking environmental knowledge and awareness to employees' green behavior. Corporate Governance: The International Journal of Business in Society, 18(1), 81103. Available at: https://doi.org/10.1108/CG-08-2016-0168.

Sarkar, A., Qian, L., \& Peau, A. K. (2020a). Overview of green business practices within the Bangladeshi RMG industry: Competitiveness and sustainable development perspective. Environmental Science and Pollution Research, 27(18), 2288822901. Available at: https://doi.org/10.1007/s11356-020-08816-y.

Sarkar, A., Qian, L., \& Peau, A. K. (2020b). Structural equation modeling for three aspects of green business practices: A case study of Bangladeshi RMG's industry. Environmental Science and Pollution Research, 27(28), 35750-35768. Available at: https://doi.org/10.1007/s11356-020-09873-z.

Schwartz, S. H. (1977). Normative influences on altruism. Advances in Experimental Social Psychology, 10, 22 1-279. Available at: https://doi.org/10.1016/s0065-2601(08)60358-5.

Shaban, S. (2019). Reviewing the concept of green HRM (GHRM) and its application practices (Green Staffing) with suggested research agenda: A review from literature background and testing construction perspective. International Business Research, 12(5), 86-94. Available at: https://doi.org/10.5539/ibr.v12n5p86.

Shah, M. (2019). Green human resource management: Development of a valid measurement scale. Business Strategy and the Environment, 28, 771-785. Available at: https://doi.org/10.1002/bse.2279.

Singh, S., Giudice, M., Chierici, R., \& Graziano, D. (2020). Green innovation and environmental performance: The role of green transformational leadership and green human resource management. Technological Forecasting and Social Change, 150, 119762. Available at: https://doi.org/10.1016/j.techfore.2019.119762.

Song, W., Yu, H., \& Xu, H. (2020). Effects of green human resource management and managerial environmental concern on green innovation. European Journal of Innovation Management, 24(3), 951-967. Available at: https://doi.org/10.1108/EJIM-11-2019-0315.

Suganthi, L. (2019). Examining the relationship between corporate social responsibilities, performance, and employees' proenvironmental behavior at work with green practices as mediator. Journal of Cleaner Production, 232, 739-750. Available at: https://doi.org/10.1016/j.jclepro.2019.05.295.

Tabachnick, B. G., \& Fidell, L. S. (2001). Using multivariate statistics (4th ed.). New York: HarperCollins.

Talapatra, S., \& Uddin, M. K. (2017). Understanding the difficulties of implementing TQM in garments sector: A case study of some RMG industries in Bangladesh. Paper presented at the 2017 International Conference on Mechanical, Industrial and Materials Engineering, Rajshahi.

Tang, G., Chen, Y., Jiang, Y., Paille, P., \& Jia, J. (2018). Green human resource management practices: Scale development and validity. Asia Pacific Journal of Human Resources, 56(1), 31-55. Available at: https://doi.org/10.1111/1744-7941.12147.

Tseng, M. L., Tan, R. R., \& Siriban-Manalang, A. B. (2013). Sustainable consumption and production for Asia: Sustainability through green design and practice. Journal of Cleaner Production, 40, 1-5. Available at: https://doi.org/10.1016/j.jclepro.2012.07.015.

Tudor, T. L., Barr, S. W., \& Gilg, A. W. (2008). A novel conceptual framework for examining environmental behavior in large organizations: A case study of the Cornwall national health service (NHS) in the United Kingdom. Environment and Behavior, 4O(3), 426-450. Available at: https://doi.org/10.1177\%2F0013916507300664. 
Unsworth, K. L., Dmitrieva, A., \& Adriasola, E. (2013). Changing behaviour: Increasing the effectiveness of workplace interventions in creating pro-environmental behaviour change. Journal of Organizational Behavior, 34(2), $211-229$. Available at: https://doi.org/10.1002/job.1837.

Vandevivere, P. C., Bianchi, R., \& Verstraete, W. (1998). Treatment and reuse of wastewater from the textile wet-processing industry: Review of emerging technologies. Journal of Chemical Technology \& Biotechnology: International Research in Process, Environmental AND Clean Technology, 72(4), 289-302.

World Bank. (2013). Bangladesh - Poverty assessment: assessing a decade of progress in reducing poverty, 2000-2010 (Bangladesh Development Series No. 31). Washington, D.C, USA: World Bank.

Yaseen, D. A., \& Scholz, M. (2018). Treatment of synthetic textile wastewater containing dye mixtures with microcosms. Environmental Science and Pollution Research, 25(2), 1980-1997. Available at: https://doi.org/10.1007/s11356-017-06337.

Yong, J. Y., Yusliza, M. Y., Ramayah, T., Chiappetta, J. C. J., Sehnem, S., \& Mani, V. (2020). Pathways towards sustainability in manufacturing organizations: Empirical evidence on the role of green human resource management. Business Strategy and the Environment, 29(1), 212-228. Available at: https://doi.org/10.1002/bse.2359.

Yusliza, M. Y., Norazmi, N. A., Jabbour, C. J. C., Fernando, Y., Fawehinmi, O., \& Seles, B. M. R. P. (2019). Top management commitment, corporate social responsibility and green human resource management. Benchmarking: An International Journal, 26(6), 2051-2078. Available at: https://doi.org/10.1108/BIJ-09-2018-0283.

Yusoff, Y., Nejati, M., Kee, D., \& Amran, A. (2018). Linking green human resource management practices to environmental performance in hotel industry. Global Business Review, 21(3), 663-680. Available at: https://doi.org/10.1177\%2F0972150918779294.

Zhang, Y., Luo, Y., Zhang, X., \& Zhao, J. (2019). How green human resource management can promote green employee behavior in China: A technology acceptance model perspective. Sustainability, 11(19), 5408. Available at: https://doi.org/10.3390/su 11195408.

Zhou, J., \& Zhang, G. (2018). Green human resource management on employees' green behavior: A model from a selfdetermination theory perspective. Human Resources Development of China, 35(7), 22-32.

Zoogah, D. B. (2011). The dynamics of green HRM behaviors: A cognitive social information processing approach. German Journal of Human Resource Management, 25(2), 117-139. Available at: https://doi.org/10.1177\%2F239700221 102500204.

Zsóka, Á., Szerényi, Z. M., Széchy, A., \& Kocsis, T. (2013). Greening due to environmental education? Environmental knowledge, attitudes, consumer behavior and everyday pro-environmental activities of Hungarian high school and university students. Journal of Cleaner Production, 48, 126-138. Available at: https://doi.org/10.1016/j.jclepro.2012.11.030.

Views and opinions expressed in this article are the views and opinions of the author(s), International Journal of Sustainable Development \& World Policy shall not be responsible or answerable for any loss, damage or liability etc. caused in relation to/arising out of the use of the content. 